\title{
Foam cell formation and cholesterol trafficking and metabolism disturbances in atherosclerosis
}

\author{
Alexandrina Volobuevaa, Dongwei Zhang ${ }^{b}$, Andrey V. Grechkoc, \\ Alexander N. Orekhov ${ }^{\mathrm{d}, \mathrm{e}}$
}

a Laboratory of Gene Therapy, Biocad Biotechnology Company, 198515 Saint-Petersburg, Russia

${ }^{b}$ Diabetes Research Center, Traditional Chinese Medicine School, Beijing University of Chinese Medicine, 100029 Beijing, China

' Federal Scientific Clinical Center for Resuscitation and Rehabilitation, 109240 Moscow, Russia

${ }^{d}$ Institute for Atherosclerosis Research, Skolkovo Innovative Center, 121609 Moscow, Russia

e Institute of General Pathology and Pathophysiology, 125315 Moscow, Russia

\section{ARTICLE INFO}

Article history:

Received: 7. 5. 2018

Received in revised form: 24. 6. 2018

Accepted: 26. 6. 2018

Available online: 25. 7. 2018

Klíčová slova:

Akumulace cholesterolu

Ateroskleróza

LDL

Pěnové buňky

\section{SOUHRN}

Pěnové buňky jsou typickými komponentami aterosklerotických plátů, v nichž aktivně participují při intracelulární akumulaci cholesterolu. Propuknutí a další progrese aterosklerózy jsou úzce spjaty s tvorbou pěnových buněk. Tyto buňky mohou pocházet jak z cirkulujicích monocytů/makrofágů, tak z rezidentních hladkých svalových buněk (VSMC), které migrují do rostoucí léze. Většinou aktivované prozánětlivé makrofágy M1 hrají důležitou roli v aterogenezi, zatímco makrofágy M2 mají protektivní roli při stabilizaci plátů. Bude třeba detailněji prozkoumat molekulární mechanismy transformace VSMC směrem k pěnovým buňkám. Lipidové kapičky, které plní pěnové buňky, vznikají z metabolizovaných modifikovaných lipoproteinů o nízké hustotě (low-density lipoproteins, LDL). LDL slouží jako hlavní zdroj lipidů, které pronikají endotel jak cestami závislými na LDL receptorech a alternativními cestami řízenými ALK-1. Za patologických podmínek může LDL podstoupit modifikaci, jako je sialylace, oxidace, glykace nebo karbamylace, které vedou k nadměrné absorpci makrofágů infiltrujících subendoteliální prostor. Modifikovaný LDL je rozpoznán především jako scavengerové receptory, jakými jsou SR-A1, CD36, LOX-1, CD68, tato exprese je nízká za fyziologických podmínek a může být zesílena prostřednictvím JNK, Wnt a signalizace NF-KB. V pěnových buňkách je LDL tráven na mastné kyseliny a volný cholesterol. Cholesterol může být esterifikovaný a dále hydrolyzovaný pro eflux na málo lipidovaný ApoA-I nebo zralý HDL. V tomto přehledovém článku se věnujeme dosavadním základním konceptům při tvorbě pěnových buněk stejně jako rozmanitým aspektům absorpce, metabolismu a poruch efluxu cholesterolu při ateroskleróze.

(c) 2019, ČKS.
Keywords:

Atherosclerosis

Cholesterol accumulation

Foam cells

LDL

\begin{abstract}
Foam cells are typical components of atherosclerotic plaques, where they actively participate in the intracellular cholesterol accumulation. Onset and further progression of atherosclerosis is tightly associated with foam cell formation. These cells can originate both from the circulating monocytes/macrophages and from the resident smooth muscular cells migrating to the growing lesion. Classically activated pro-inflammatory M1 macrophages play an important role in atherogenesis, while M2 macrophages have a protective role in plaque stabilization. Molecular mechanisms for VSMC transformation towards foam cells remains to be studied in detail. Lipid droplets filling the foam cells are generated from metabolized modified low-density lipoproteins (LDL). LDL serves as the main source or lipids, which penetrate the endothelium both via LDL-receptor-dependent and alternative ALK-1-regulated pathways. Under pathologic conditions, LDL can undergo modification, such as sialylation, oxidation, glycation or carbamylation, leading to its excessive uptake by macrophages infiltrating the subendothelial space. Modified LDL is recognized mainly by scavenger receptors, such as SR-A1, CD36, LOX-1, CD68, those expression is low under physiological conditions and can be upregulated via JNK, Wnt and NF-KB signaling. In foam cells LDL is digested to fatty acids and free cholesterol. Cholesterol can be esterified and further hydrolyzed for efflux to poorly lipidated ApoA-I or mature HDL. In this review, we discuss the basic concepts in foam cell formation established so far, as well as different aspects of cholesterol uptake, metabolism and efflux disturbances in atherosclerosis.
\end{abstract}

Address: Alexander N. Orekhov, Laboratory of Angiopathology, Institute of General Pathology and Pathophysiology, Moscow 125315, Russia, e-mail: a.h.opexob@gmail.com DOI: 10.1016/j.crvasa.2018.06.006 


\section{Introduction}

Pathogenesis of atherosclerosis is complex and includes both changes in lipid metabolism and alterations at the cellular level in the affected arterial wall. This also makes the search for novel therapeutic approaches challenging, since multiple potential targets should be evaluated and combined in order to develop an efficient treatment. The inflammatory component of atherosclerosis pathogenesis is of key importance. Local inflammation in the vessel wall leads to atherosclerotic lesion development and is associated with formation of foam cells. These cells were named based on their microscopic appearance, which is explained by the massive lipid accumulation in the cytoplasm. Foam cells can derive from both monocytes-macrophages recruited to the lesion site from the bloodstream and from the resident vascular smooth muscle cells (VSMCs). Massive intracellular lipid accumulation causing the formation of foam cells results from the enhanced modified low-density lipoprotein ( $m L D L$ ) uptake and the reduced ability of the cells to process cholesterol and transfer it to high-density lipoproteins (HDL).

Under normal conditions, LDL particles function as lipid carriers delivering the fuel molecules to organs and tissues from the liver. Native (unmodified) LDL is not atherogenic, as defined by the inability to induce lipid accumulation in cultured cells. ${ }^{1}$ However, under pathologic conditions, LDL can be subjected to modifications, such as sialylation, oxidation, glycation, carbamylation, that make it pro-atherogenic. The exact mechanisms of LDL modifications remain to be studied. The first known atherogenically modified LDL, oxLDL, could not be found in vivo, although it can probably be localized to the su- bendothelial space in the atherosclerotic lesion areas. One intriguing possibility is that LDL modification occurs as a series of multiple steps, starting with desialylation, followed by changes of the particle size and density, as well as electric charge, and, finally, oxidation and formation of highly-atherogenic aggregates. There is currently enough data available to support this hypothesis. ${ }^{2}$ In any case, atherogenic modification has a profound influence on LDL particle properties, altering its recognition by the cellular surface receptor (LDL-R) and resulting in an alternative internalization way mediated by scavenger receptors. Modified LDL therefore affects the arterial wall cells and can even have potent cytotoxic effect, as it has been shown for oxLDL. ${ }^{3}$ Moreover, $\mathrm{mLDL}$ can also trigger formation of immune complexes that further enhance the pathologic process. ${ }^{4}$

In this review, we will focus on various aspects of LDL participation in foam cell formation in atherosclerosis.

\section{Vascular permeability and LDL trafficking in the arterial wall}

According to the current understanding, endothelial dysfunction is the first step in the development of atherosclerotic lesions. Local damage of the endothelium occurs most frequently at the sites if disturbed laminar flow, such as vessel bifurcations or bends. This, in turn, leads to increased permeability of the endothelium, which facilitates LDL entry into the subendothelial space (Fig. 1). Several risk factors for the increased vascular permeability to $\mathrm{mLDL}$ have been identified, including dyslipidemia, diabetes, hypertension, obesity and smoking. mLDL

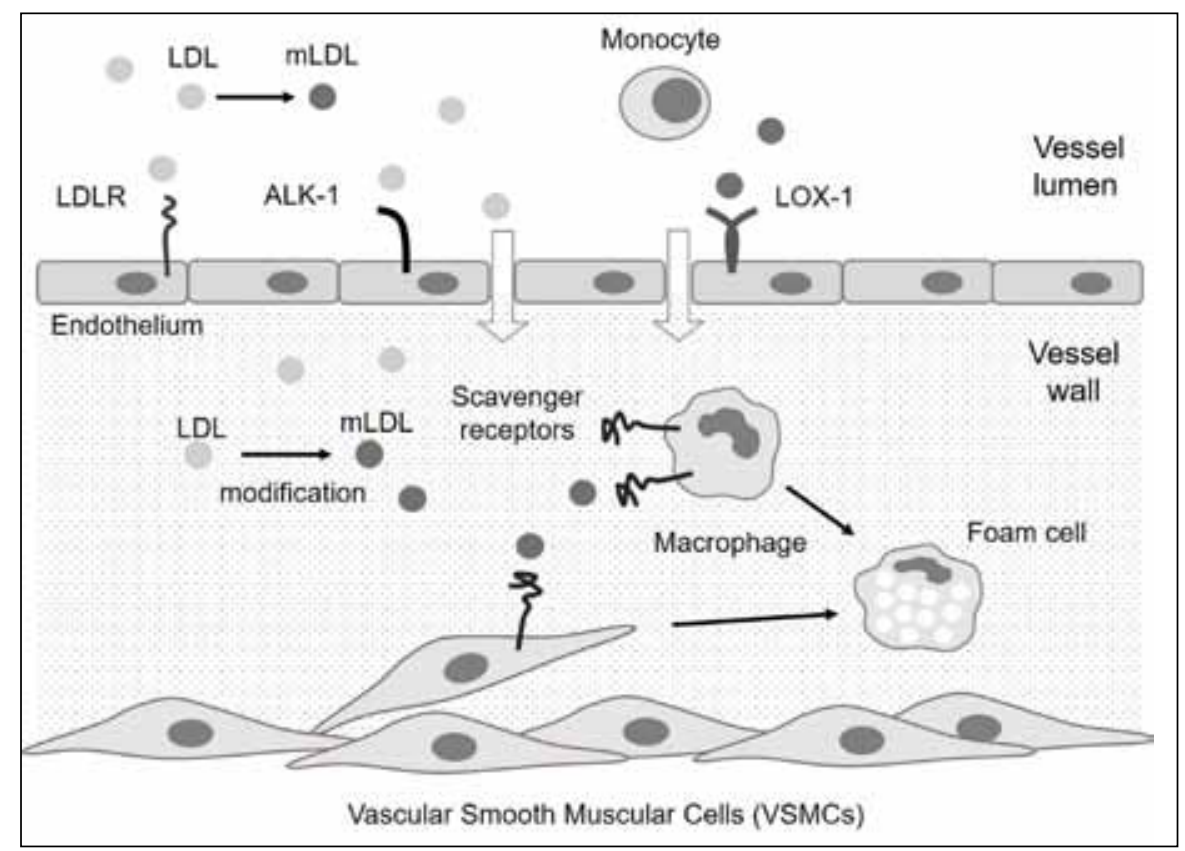

Fig. 1 - Simplified scheme of foam cells formation in the subendothelial space. LDL and $\mathrm{mLDL}$ particles penetrate the subendothelial space via several pathways. Once inside the vascular wall, they can be taken up by macrophages and VSMCs that acquired phagocytic phenotype. The large part of $\mathrm{mLDL}$ is internalized into the cells via scavenger receptors. Foam cells are responsible for the intracellular lipid storage in the growing atherosclerotic plaque. 
entry into the subendothelial space and activation of the endothelial cells lead to the development of local inflammatory process. Lipid accumulation in the arterial intima is known as fatty streaks - the earliest macroscopically visible stage of atherosclerosis. ${ }^{5}$ At the microscopic level, these lesions are characterized by the presence of aggregated lipoprotein particles and cholesterol crystals in the affected cells, as demonstrated by 3D electron microscopy of human carotid atherosclerotic plaques. ${ }^{6}$

The surface of the endothelial cells is covered by glycocalyx composed of glycoproteins, proteoglycans, and hyaluronan, which is the first barrier of the endothelial wall for LDL and other circulating agents. ${ }^{7}$ Regions of the arterial wall susceptible to atherosclerosis, such as above-mentioned bifurcation sites, have signs of glycocalyx breakdown. Local inflammatory process is accompanied by the production of reactive oxygen/nitrogen species (ROS/RNS) and activation of matrix metalloproteinases (MMPs), heparanase and sialidases. ROS, such as superoxide, carbonate radical anions $\left(\mathrm{CO}_{3}^{-}\right)$and the hydroxyl radical $(\mathrm{OH})$, modify other oxygen species, DNA, lipids and proteins. MMP expression and activity is induced by ROS, cytokines, shear stress, hypoxia and hormones. MMP cleave the protein core of proteoglycans, thereby leading to destabilization of the vascular wall. Heparanase contribute to glycocalyx damage via degradation of HS chains at sites of low sulfation causing the loss of the HS-bound extracellular superoxide dismutase (ecSOD), which normally protects the endothelium from excessive ROS production. Extracellular hyaluronidases generate low molecular weight HA oligosaccharides that contribute to ROS production and increase the glycocalyx permeability. Moreover, these mediators can mutually activate each other, further enhancing the pathological process. ROS/RNS-generating enzymes and sialidases decrease bioavailability of NO, which has protective vasodilating properties, and thereby support vasoconstriction. ${ }^{8,9}$

After crossing the glycocalyx, LDL particles can further penetrate the endothelium via transcytosis, a process combining receptor-mediated endocytosis by clathrin-coated and caveolin vesicles with exocytosis. The organization and functions of caveolae are mediated by caveolin-1 and adapter protein-cavin-1, which stabilizes caveolin-1. Caveolin-1 mediates endocytosis and transcytosis of LDL in the endothelial cells and maintains endothelial nitric oxide synthase (eNOS) in an inactive state. Both caveolin-1 and cavin-1 down-regulation inhibits LDL uptake and transcytosis. ${ }^{10}$

Caveolae and clathrin-coated vesicles bind LDL mostly via the LDL-R, which is internalized, shuttled through the endothelium, and delivered at the abluminal membrane. LDL-R expression differs among tissues. A recent study showed that it is expressed at the apical plasma membrane of brain endothelial cells in mice and rats and therefore can potentially be used for transport of drugs across the blood-brain barrier. The authors showed that different LDL-R-binding peptides were efficient vectors with potential for the transendothelial transfer of different classes of molecules. ${ }^{11}$ Besides transcytosis, LDL can also cross the endothelium through the paracellular pathway.

Another way of LDL particles internalization is the LDLR-independent pathway, which potentially can account for
$40-50 \%$ of LDL internalization through a non-lysosomal, non-degradative pathway. It is enhanced in case of hypercholesterolemic concentrations of LDL. A recent work used an unbiased, genome-wide screening approach to demonstrate that native LDL can be directly bound by activin-like kinase 1 (ALK1) ectodomain with lower affinity at hypercholesterolemic concentrations. In vitro data clearly proved that ALK1 can be considered a novel low affinity high-capacity receptor for LDL in endothelial cells mediating its uptake via an unusual endocytic pathway that diverts the ligand from the lysosomal degradation and promotes LDL transcytosis. ${ }^{12}$ Taking into consideration its role in BMP signaling, it is questionable whether ALK1 may serve as promising therapeutic target for atherosclerosis prevention. Nevertheless, this work provides a good example of LDLR-independent pathway of LDL internalization.

Unlike native $L D L, m L D L$ is recognized mainly by scavenger receptors, such as LOX-1 on endothelium. The expression of this receptor is low under physiological conditions, but can be increased by oxLDL, pro-inflammatory cytokines, pro-oxidative and biomechanical stimuli. ${ }^{13}$ It has been demonstrated that LOX-1 overexpression in an atherosclerosis-prone background impairs the endothelial function. ${ }^{14}$ Interestingly, inhibition of LOX-1 gene reduces NF-KB activation and the inflammatory and hypoxia pathways, suggesting a mechanistic connection between cancer and atherosclerosis. ${ }^{15}$

It is plausible that $\mathrm{mLDL}$ transported by the non-selective pathway mediated by scavenger receptors is a major source of lipids accumulating in the growing atherosclerotic lesions. However, native LDL entering the subendothelial space as a consequence of increased endothelial permeability also can serve as such source, as a result of atherogenic modification and/or formation of complexes with the extracellular matrix components. ${ }^{16}$

\section{Macrophages and VSMC are major source of foam cells in atherosclerosis}

According to current understanding, both macrophages recruited to the lesion site and resident vascular cells can become foam cells. It was shown that in human coronary lesions the proportion of foam cells of VSMC origin is higher than $50 \%$, which is higher than previously thought. ${ }^{17}$

Chronic inflammation associated with atherosclerosis is a subject of active research, partly because it is promising for identifying new therapeutic approaches. ${ }^{18}$ Inflamed endothelium stimulates the production of pro-inflammatory cytokines, including interleukin-6 (IL-6), monocyte chemotactic protein 1 (MCP-1) and adhesion molecules intercellular adhesion molecule 1 (ICAM-1), vascular cell adhesion molecule 1 (VCAM-1), and E-selectin. These effectors recruit the monocytes penetrating into the intima and differentiating into macrophages.

Following the traditional phenotypic classification of macrophages, 2 types of them can be defined: classically activated pro-inflammatory M1 macrophages and alternatively activated M2 macrophages that have anti-inflammatory properties and are responsible for tissue repair 
and remodeling. More recent studies made it evident that macrophage differentiation is much more complex, and several additional subsets have been defined to date. ${ }^{19}$ Pro-inflammatory M1 macrophages produce high levels of pro-inflammatory cytokines and ROS/NOS, while M2 macrophages are associated with wound healing, tumor growth, helminth infections and Th2 type responses. In the field of atherosclerosis, it is generally accepted that M1 macrophages play an important role in atherogenesis, while M2 macrophages have a protective role in plaque stabilization. It was shown that M1 phenotype can be guided by epigenetic modifying enzyme (KDM4A [JMJD2A]), which acts independently of NF- $\kappa B$ and HIF activation, two signals critical for pro-inflammatory activation of macrophages. ${ }^{20}$ Shift from $\mathrm{M} 1$ to $\mathrm{M} 2$ phenotype indicative of atherosclerotic plaque regression is promoted by various transcription factors including Maf family of transcription factors (MafB, which facilitates macrophage cholesterol efflux). ${ }^{21}$

A recent study suggested that $\mathrm{M} 1 / \mathrm{M} 2$ polarization can be regulated by endothelial extracellular vesicles (EV), which are known to play a pivotal role in cell-to-cell communication. EVs from KLF2-expressing endothelial cells suppressed monocyte activation in vitro. Furthermore, atherosclerotic lesions were reduced in mice that received EVs from KLF2-transduced endothelial cells with a shift from $M 1$ to $M 2$ macrophages due to decreased expression of pro-inflammatory miR-155.22 Other studies have demonstrated the importance of miRNA signaling in atherosclerosis progression. For example, miR-195 levels were increased in IL-10-treated human primary macrophages, and this miRNA decreased levels of IL-1 $\beta$, IL- 6 and TNF- $\alpha$ pro-inflammatory cytokines in the supernatants of M1-stimulated macrophages in vitro. Moreover, miR-195 inhibited the capacity of M1 macrophages to promote VSMC migration to the lesion area, where they become lipid loaded foam cells. ${ }^{23}$

Transformation of VSMC into foam cells remains to be studied in detail. Unlike skeletal or heart SMCs, VSCMs retain a high degree of dedifferentiation potential and plasticity and can be transformed from a contractile to a synthetic type. This shift is known as SMC phenotypic modulation or switching, typical for SMCs accumulating in the intima during the formation of atherosclerotic lesions. Under these conditions, SMCs acquire macrophage-like phenotype and express both $\alpha$-SMA and CD68, which is typical for macrophages and indicates the ability to phagocytosis. ${ }^{24}$

In VSMCs, oxLDL exhibits a dual biological effect: moderate concentrations of mildly oxidized LDL are pro-inflammatory and trigger cell migration and proliferation, while higher concentrations induce cell growth arrest and apoptosis. It is likely that VSMCs are converted to macrophages upon cholesterol loading by increase of KLF4 followed by downregulation of miR-143/145/SRF/MYOCD complex. ${ }^{48}$ Besides, VSMCs can acquire pro-inflammatory cell phenotype and release inflammatory cytokines, including IL-1 $\beta$, IL- 6 and MCP-1 and express inflammatory molecules, such as ICAM-1 and VCAM-1..$^{50-54}$ Moreover, they were shown to release related to plaque vulnerability MMP-9 upon loading with lipids. ${ }^{49}$ In atherosclerotic plaque, ICAM-1 is also upregulated on the surface of VSMCs and promotes adhesion to monocyte/macrophages and T cells. ${ }^{15}$ Recently, a role of CXCL12/CXCR4 chemokine ligand/receptor axis in VSMC fate was demonstrated in apolipoprotein E-deficient mouse model of atherosclerosis. It was shown that CXCR4 deficiency favored a synthetic phenotype of arterial VSMCs in the lesions and impaired cholesterol efflux. ${ }^{25}$ The transmembrane orphan receptor endosialin (CD248) - a marker of activated VSMCs - may also display functional involvement in the pathogenesis of atherosclerosis by regulating the pro-inflammatory phenotype of VSMC in vitro and in vivo. ${ }^{26}$

\section{LDL uptake, metabolism and efflux in foam cells}

\section{LDL uptake}

Expression of scavenger receptors regulating lipid uptake plays an important role in foam cell formation and the subsequent atherosclerotic plaque development. Both macrophages and VSMCs express scavenger receptors mediating $\mathrm{mLDL}$ uptake. The most studied among them are SR-A1, CD36, LOX-1, CD68 ncreased expression of scavenger receptors is generally associated with enhanced mLDL uptake.

Expression of scavenger receptors is dependent on various signaling pathways. For instance, JNK activation and corresponding upregulation of CD14 and SR-Al pathway mediates LPS-induced oxLDL uptake. Upon activation, JNK is translocated into the nucleus, where it phosphorylates c-Jun and triggers the target gene transcription. Jun and Fos are family members of the transcription factor activator protein-1 (AP1), which is critical for expression of CD14 and SR-AI. ${ }^{27}$ It was shown that CD36 expression is positively regulated by Wnt5a signaling both in human carotid atherosclerotic tissue and THP-1-derived macrophages. ${ }^{28}$ Inhibition of this signaling pathway prevented lipid accumulation and CD36 up-regulation. Non-coding RNA also affects scavenger receptors expression. For instance, oxLDL upregulates the expression of long non-coding RNA MALAT1 in THP-1-derived macrophages through the NF- $\kappa B$ pathway. Under the oxLDL treatment, MALAT1 recruits $\beta$-catenin to binding sites on the CD36 promoter, inducing CD36 expression. ${ }^{29}$ Liver kinase B1 (LKB1) - a serine/threonine kinase and tumor suppressor - phosphorylates SR-A resulting in its lysosome degradation. In macrophages exposed to oxLDL, LKB1 expression is downregulated favoring the expression of SRA and $\mathrm{mLDL}$ uptake. ${ }^{30}$

Recently, a novel link between vascular lipid uptake and inflammation via miRNA regulation was demonstrated. It was shown that in VSMCs, anti-inflammatory IL-19 induces the expression of miR133a, a muscle-specific miRNA, which in turn reduces lipid accumulation. This miRNA targets and reduces mRNA of LDL-R adaptor protein 1, (LDLRAP1), an adaptor protein which functions to internalize the LDL-R, thereby lowering LDL uptake. ${ }^{31}$

\section{Lipid metabolism in foam cells}

In macrophages, LDL particles are digested in the lysosomes by lysosomal acid lipase (LAL) to release free cholesterol and fatty acids. Loss-of-function mutations in LAL gene are associated with Wolman disease, a rare auto- 
somal recessive cholesterol fatty acid esters (CE) storage disease and accelerated atherosclerosis. ${ }^{32}$ In the endoplasmic reticulum (ER), free cholesterol can then be re-esterified to CE, which is stored in the lipid droplets of foam cells. CE synthesis is catalyzed by acetyl coenzyme A: cholesterol acyltransferase (ACAT) isoenzymes: ACAT1 and ACAT2, encoded by the SOAT1 and SOAT2 (sterol O-acyltransferase) genes, respectively. Unlike ACAT1, which is widely expressed in different tissues, distribution of ACAT2 is almost exclusively restricted to the intestinal epithelial cells and hepatocytes. Though therapeutic targeting of ACAT1 (SOAT1) seems an option, it was shown that inhibition of ACAT1 leads to significant accumulation of cholesterol in the ER. ${ }^{33}$

Alternatively, CE can be hydrolyzed by enzymes collectively named as neutral CE hydrolases (hormone-sensitive lipase [HSL]; carboxylesterase 1 [CEH or CES1] and neutral cholesterol ester hydrolase 1 [NCEH1]) and LAL.

Accumulation of cellular cholesterol leads to activation of several transcription factors, including the liver $X$ receptors (LXRs), the retinoid $x$ receptor ( $R x r$ ) and members of the peroxisome proliferator-activated receptor (PPAR) family, such as PPAR- $\alpha$ and PPAR- $\gamma .{ }^{34}$ Lxr and Rxr form heterodimers and stimulate the expression of the ATP-binding cassette subfamily $A$ member 1 (ABCA1) and ABCG1 that regulate free cholesterol efflux (reverse transport) to poorly lipidated ApoA-I apolipoproteins and to mature $\mathrm{HDL}$, correspondingly. Passive efflux of free cholesterol is also occurring via simple diffusion or SR-BI-mediated pathway. Reverse cholesterol transfer (RCT) is a process through which excess cholesterol from peripheral cells and tissues returns to the liver for excretion and is considered anti-atherosclerotic. ${ }^{35}$ Cholesterol efflux by macrophages is the first step of RCT that occurs in the atherosclerotic blood vessel wall. Therefore, its components are considered promising therapeutic targets. ${ }^{35-37}$ Neutrophil elastase (NE) - a serine proteinase - suppresses cholesterol efflux in vitro and in vivo by enhancing degradation of $A B C A 1$ protein. Its deficiency leads to increased $A B C A 1$ protein level and less lipid loading in macrophages from mice fed on high fat diet aortas. Therefore, inhibition of NE may represent a potential therapeutic approach to treat cardiovascular diseases. ${ }^{38}$ Proprotein convertase subtilisin/ kexin type 9 (PCSK9) inhibits ABCA1-mediated cholesterol efflux induced by LXR/RXR agonists in mouse peritoneal macrophages and in acetylated LDL-treated macrophages with a reduction of $A B C A 1$ protein expression. ${ }^{39}$

In bone marrow-derived macrophages, MC1-R activation by $\alpha$-melanocyte-stimulating hormone and selective MC1-R agonists upregulates the levels of $A B C A 1$ and $A B C G 1$, enhances cholesterol efflux and reduces cell surface CD36 expression. These findings were supported by in vivo data. ${ }^{40}$ Role of MCR-1 in prevention of atherosclerosis was further supported by results of in vivo study in mice deficient in apolipoprotein $\mathrm{E}$, carrying dysfunctional MC1-R and put on a high-fat diet. ${ }^{41}$

Scavenger receptor class B type I (SR-BI) is known as a receptor for HDL. Loss of SR-B1 impairs the uptake of HDL lipids leading to inability of HDL to promote cholesterol efflux and prevent inflammation. ${ }^{42}$

Using bioinformatic predictions and luciferase reporter assays the association between miR-24 and the SR-BI 3' untranslated region ( $3^{\prime}$ UTR) was detected. miR-24 directly repressed SR-BI expression by targeting its $3^{\prime} U T R .^{43}$

In human and animal cell lines, toll-like receptor 2 (TLR2) reduced ABCA1, ABCG1 and SR-B1 expression at the transcriptional and translational levels in a dose-dependent manner. TLR2 may be involved in the activation of cholesterol efflux in macrophages by regulating the NF-KB signaling pathway. ${ }^{44}$

Recently it was suggested that restoration of autophagy via modulation of thermosensitive cation channel transient receptor potential vanilloid subfamily 1 (TRPV1) can be a possible approach for cell protection against atherosclerosis. ${ }^{47}$ It was demonstrated that coupling of copper sulfide (CUS) nanoparticles to antibodies targeting TRPV1 act as a photothermal switch for TRPV1 signaling: upon irradiation and local increases of temperature, TRPV1 channel was opened, which was followed by $\mathrm{Ca}^{2+}$-AMPK signaling pathway activation and ABCA1-dependent cholesterol efflux. These processes appeared to restore autophagy and impede foam cell formation in VSMCs treated with oxLDL in vitro and attenuate atherosclerotic lesion development in $\mathrm{ApoE}^{-/-}$mice.

Foam cell lipid droplets also contain triacylglycerol and phosphatidylcholine which are produced in the glycerolipid synthesis pathway. This pathway contributes to foam cell formation and includes four enzymatic steps in which glycerol-3-phosphate is converted into triacylglycerol or phosphatidylcholine at the endoplasmic reticulum. Glycerolipid synthesis pathway influences mLDL-elicited pro-inflammatory responses. Lipin-1 is a key regulatory enzyme in the glycerolipid synthetic pathway with both enzymatic phosphatidic acid phosphatase activity and transcriptional cofactor activity. It was demonstrated that loss of myeloid-associated lipin-1 enzymatic activity results in reduced atherosclerosis in mice fed with high-fat diet for 8 and 12 weeks. Lipin- 1 enzymatic activity contributes to foam cell formation and regulates a diacylglycerol-dependent signaling cascade resulting in persistent AP-1 activation in response to $\mathrm{mLDL}$. In turn, activation of AP-1 primes the macrophage to be hyperresponsive to lipopolysaccharide-induced TNF- $\alpha$ production. It was demonstrated that stimulation of macrophages with both oxLDL and acetylated LDL results in sustained phosphorylation of the PKC $\alpha / \beta$ II-ERK $1 / 2$-cJun pathway up to 48 hours. It is likely that oxLDL elicits persistent diacylglycerol generation that leads to AP-1 activation via a PKC $\alpha$ / BII- ERK $1 / 2-c J u n$ signaling axis in macrophages. ${ }^{45}$

Using liposomes containing particular acyl chains (phosphatidylserine [PS] liposomes containing phosphatidylcholine and cholesterol) the effect of various acyl chains on foam cell development was examined. It was discovered that unsaturated (C18:1), but not saturated (C16:0 and $\mathrm{C} 18: 0)$, PS liposomes induced lipid droplet formation, indicative of foam cell phenotype. These results suggested that the acyl chain preference of macrophages could have some impact on their progression to foam cells. ${ }^{46}$

\section{Conclusion}

Atherosclerosis is associated with impaired cholesterol metabolism in foam cells: cholesterol uptake is increased 
due to endothelial leakage and scavenger receptor upregulation while cholesterol efflux is downregulated. It is now accepted that both VSCM and macrophages can be converted to foam cells under the conditions existing in atherosclerotic lesions, hence increased LDL and $\mathrm{mLDL}$ presence and local inflammation. Different signaling pathways participate in foam cell formation and are a subject of ongoing studies. Further studies are needed to search for novel molecular targets for atherosclerosis treatment.

\section{Conflict of interest}

The authors declare no conflict of interest.

\section{Funding}

This work was supported by Russian Science Foundation (Grant \# 18-15-00254).

\section{Author's contribution}

AV wrote the manuscript; DZ, AVG and ANO reviewed and edited the text.

\section{Ethical statement}

Authors state that the research was conducted according to ethical standards.

\section{References}

1. Sobenin IA, Chistiakov DA, Bobryshev YV, Orekhov AN. Blood atherogenicity as a target for anti-atherosclerotic therapy. Curr Pharm Des 2013;19:5954-5962.

2. Alipov V, Sukhorukov V, Karagodin V, et al. Chemical composition of circulating native and desialylated low density lipoprotein: what is the difference? Vessel Plus 2017;1:107115.

3. Rossman C. Ethyl pyruvate inhibits oxidation of LDL in vitro and attenuates oxLDL toxicity in EA.hy926 cells. PLoS One. 2018;13(1):e0191477.

4. Sobenin IA, Salonen JT, Zhelankin AV, et al. Low density lipoprotein-containing circulating immune complexes: role in atherosclerosis and diagnostic value. Biomed Res Int 2014;2014:205697.

5. Mundi S. Endothelial permeability, LDL deposition, and cardiovascular risk factors - a review. Cardiovasc Res 2018;114:35-52.

6. Lehti S. Extracellular Lipids Accumulate in Human Carotid Arteries as Distinct Three-Dimensional Structures and Have Proinflammatory Properties. Am J Pathol 2018;188:525-538.

7. Sievi I. Regulation and function of endothelial glycocalyx layer in vascular diseases. Vascul Pharmacol 2018;100:26-33.

8. Mytra R. Glycocalyx in Atherosclerosis-Relevant Endothelium Function and as a Therapeutic Target. Curr Atheroscler Rep 2017;19:63.

9. Bai X. Cavin-1 regulates caveolae-mediated LDL transcytosis: crosstalk in an AMPK/eNOS/ NF- $\mathrm{BB} / \mathrm{Sp} 1$ loop. Oncotarget 2017;8:103985-103995.

10. Molino $\mathrm{Y}$. Use of LDL receptor - targeting peptide vectors for in vitro and in vivo cargo transport across the blood-brain barrier. FASEB J 2017;31:1807-1827.

11. Kraehling JR. Genome-wide RNAi screen reveals ALK1 mediates LDL uptake and transcytosis in endothelial cells. Nat Commun 2016;7:13516.

12. Hofman A. Contribution of lectin-like oxidized low-density lipoprotein receptor-1 and LOX-1 modulating compounds to vascular diseases. Vascul Pharmacol 2017 Oct 19. pii: S15371891(17)30171-4.

13. Hofman A. Lectin-like oxidized low-density lipoprotein receptor-1 promotes endothelial dysfunction in LDL receptor knockout background. Atheroscler Suppl 2017;30:294-302.
14. Balzan S. LOX-1 receptor: A potential link in atherosclerosis and cancer. Life Sci 2018 Feb 17. pii: S0024-3205(18)30080-8.

15. Allahverdian S. Smooth Muscle Cell Fate and Plasticity in Atherosclerosis. Cardiovasc Res. 2018 Jan 27. doi: 10.1093/cvr/cvy022. [Epub ahead of print]

16. Camejo G, Hurt-Camejo E, Wiklund O, Bondjers G. Association of apo B lipoproteins with arterial proteoglycans: pathological significance and molecular basis. Atherosclerosis 1998;139:205-222.

17. Shirai R. Neopterin Counters Vascular Inflammation and Atherosclerosis. J Am Heart Assoc 2018 Feb 2;7(3). pii: e007359.

18. Wang $X$. Identification of the histone lysine demethylase KDM4A/JMJD2A as a novel epigenetic target in M1 macrophage polarization induced by oxidized LDL. Oncotarget 2017;8:114442-114456.

19. Guilliams M, van de Laar L. A Hitchhiker's Guide to Myeloid Cell Subsets: Practical Implementation of a Novel Mononuclear Phagocyte Classification System. Front Immunol 2015;6:406.

20. Kim H. The transcription factor MafB promotes antiinflammatory M2 polarization and cholesterol efflux in macrophages. Sci Rep 2017;7:7591.

21. He. S. Endothelial extracellular vesicles modulate the macrophage phenotype: Potential implications in atherosclerosis. Scand J Immunol 2018 Feb 21. doi: 10.1111/ sji.12648. [Epub ahead of print]

22. Bras J. miR-195 inhibits macrophages pro-inflammatory profile and impacts the crosstalk with smooth muscle cells. PLoS One 2017;12(11):e0188530.

23. Döring Y. Vascular CXCR4 Limits Atherosclerosis by Maintaining Arterial Integrity: Evidence From Mouse and Human Studies. Circulation 2017;136:388-403.

24. Andreeva ER, Pugach IM, Orekhov AN. Subendothelial smooth muscle cells of himan aorta express macrophage antigen in situ and in vitro. Atherosclerosis. 1997;165:19-27.

25. Hasanov Z. Endosialin Promotes Atherosclerosis Through Phenotypic Remodeling of Vascular Smooth Muscle Cells. Arterioscler Thromb Vasc Biol 2017;37(3):495-505.

26. An D. JNK1 Mediates Lipopolysaccharide-Induced CD14 and SR-Al Expression and Macrophage Foam Cell Formation. Front Physiol 2018;8:1075.

27. Ackers I. Blocking Wnt5a signaling decreases CD36 expression and foam cell formation in atherosclerosis. Cardiovasc Pathol 2018;34:1-8.

28. Huangfu N. LncRNA MALAT1 regulates oxLDL-induced CD36 expression via activating $\beta$-catenin. Biochem Biophys Res Commun 2018:495:2111-2117.

29. Lui Z. Macrophage Liver Kinase B1 Inhibits Foam Cell Formation and Atherosclerosis. Circ Res 2017;121:1047-1057.

30. Gabunia K. Induction of MiR133a expression by IL-19 targets LDLRAP1 and reduces oxLDL uptake in VSMC. J Mol Cell Cardiol 2017; 105:38-48.

31. Morris G. Coronary Artery Disease-Associated LIPA Coding Variant rs1051338 Reduces Lysosomal Acid Lipase Levels and Activity in Lysosomes. Arterioscler Thromb Vasc Biol 2017;37:1050-1057.

32. Geng F. Lipid droplets, potential biomarker and metabolic target in glioblastoma. Intern Med Rev (Wash D C). 2017 May;3(5). doi: 10.18103/imr.v3i5.443.

33. Chinetti-Gbaguidi G. PPAR $\beta$ in macrophages and atherosclerosis. Biochimie 2017;136:59-64.

34. Se-Jin Jeong. The Role of Macrophage Lipophagy in Reverse Cholesterol Transport. Endocrinol Metab (Seoul) 2017;32:41-46.

35. Zou TB1, Zhu SS1, Luo F, et al. Effects of Astaxanthin on Reverse Cholesterol Transport and Atherosclerosis in Mice. Biomed Res Int 2017;2017:4625932.

36. Chen X. 2,3,4',5-tetrahydroxystilbene-2-O- $\beta$ - $d$-glycoside attenuates atherosclerosis in apolipoprotein E-deficient mice: role of reverse cholesterol transport. Can J Physiol Pharmacol 2018;96:8-17.

37. Pizzini A. The Role of Omega-3 Fatty Acids in Reverse Cholesterol Transport: A Review. Nutrients. 2017 Oct 6;9(10). pii: E1099.

38. Wen G. Genetic and Pharmacologic Inhibition of the Neutrophil Elastase Inhibits Experimental Atherosclerosis. J Am Heart Assoc 2018 Feb 8;7(4). pii: e008187. 
39. Adorni M. Inhibitory effect of PCSK9 on Abca1 protein expression and cholesterol efflux in macrophages. Atherosclerosis 2017;256:1-6.

40. Rinne P. Melanocortin 1 Receptor Signaling Regulates Cholesterol Transport in Macrophages. Circulation 2017;136:83-97.

41. Rinne P. Melanocortin 1 Receptor Deficiency Promotes Atherosclerosis in Apolipoprotein $\mathrm{E}^{-1-}$ Mice. Arterioscler Thromb Vasc Biol 2018;38:313-323.

42. Linton F. SR-BI: A Multifunctional Receptor in Cholesterol Homeostasis and Atherosclerosis. Trends Endocrinol Metab 2017;28:461-472.

43. Ren K. MicroRNA-24 aggravates atherosclerosis by inhibiting selective lipid uptake from HDL cholesterol via the posttranscriptional repression of scavenger receptor class B type $\mathrm{I}$. Atherosclerosis 2018;270:57-67.

44. Liy Y. Toll-like receptor 2 downregulates the cholesterol efflux by activating the nuclear factor-кB pathway in macrophages and may be a potential therapeutic target for the prevention of atherosclerosis. Exp Ther Med 2018;15:198-204.

45. Vozenilek AE. Macrophage-Associated Lipin-1 Enzymatic Activity Contributes to Modified Low-Density Lipoprotein-Induced Proinflammatory Signaling and Atherosclerosis. Arterioscler Thromb Vasc Biol 2018;38:324-334.

46. Fujiwara Y. Acyl Chain Preference in Foam Cell Formation from Mouse Peritoneal Macrophages. Biol Pharm Bull 2018;41:86-91.
47. Gao W. Copper sulfide nanoparticles as a photothermal switch for TRPV1 signaling to attenuate atherosclerosis. Nat Commun 2018;9:231.

48. Vengrenyuk $Y$. Cholesterol loading re-programs the miR-143/145-myocardin axis to convert aortic smooth muscle cells to a dysfunctional macrophage-like phenotype. Arterioscler Thromb Vasc Biol 2015;35:535-546.

49. Langley ER. Extracellular matrix proteomics identifies molecular signature of symptomatic carotid plaques. J Clin Invest 2017;127:1546-1560.

50. Dautova Y. Calcium phosphate particles stimulate interleukin$1 \beta$ release from human vascular smooth muscle cells: A role for spleen tyrosine kinase and exosome release. J Mol Cell Cardiol 2018:115:82-93.

51. Verzola D. Myostatin mediates abdominal aortic atherosclerosis progression by inducing vascular smooth muscle cell dysfunction and monocyte recruitment. Sci Rep 2017;3;7:46362.

52. A novel protective function of 5-methoxytryptophan in vascular injury. Sci Rep 2016;6:25374.

53. Lee GL TLR4-Activated MAPK-IL-6 Axis Regulates Vascular Smooth Muscle Cell Function. Int J Mol Sci 2016 Aug 24;17(9)

54. Byskov K. Factor VII activating protease (FSAP) regulates the expression of inflammatory genes in vascular smooth muscle and endothelial cells. Atherosclerosis 2017;265:133-139. 